\title{
SCIENTIFIC APPROACH TO DETERMINING THE VECTORS OF INNOVATIVE DEVELOPMENT OF INDUSTRIAL ENTERPRISES
}

\author{
Alla Dunska', Kateryna Boiarynova², Maryna Kravchenko³
}

\begin{abstract}
The purpose of the paper is to form a scientific and methodological approach to determining the vectors of innovative development of industrial enterprises as a tool for establishing the trajectory of innovation in terms of development of innovation potential and environmental impact. Correlation analysis of these factors as indicators of external (external environment of the enterprise) and internal (innovative potential) environment based on the nature and direction of influences allows to establish the vector of development, and the construction of a forecast model of economic results confirms its correctness. Methodology. The research used its own methodological developments, correlation analysis, formed the parameters of the external environment, innovation potential, the results of enterprises. The approach was tested at the enterprises of the pulp and paper industry of Ukraine, which proved its effectiveness and efficiency. Results. The ideology of the proposed approach on the combination of organizational and managerial aspects of innovative development with economic indicators is formed and substantiated. The types of target innovation orientation of the enterprise, which is formed into a bipolar matrix, are determined. Based on the corresponding trajectory of the transition between the components of the matrix, three key vectors of development are formed: innovation-adaptive, innovation-balanced, innovation-concentrated. Practical implications. On the example of enterprises of the pulp and paper industry their vectors of development, forecast indicators of profit and sales revenues as an economic effect of following the vector direction and the trajectory of innovation are designed. Value/originality. The developed scientific and methodological approach involves the establishment of the vector of innovative development of the enterprise on the interdependence of innovation potential and the nature of the impact of the external environment, which provides an opportunity to predict the results of its operation.
\end{abstract}

Key words: innovative development, vectors, industrial enterprise, methodical approach.

JEL Classification: O32, M11, L65.

\section{Introduction}

The slowdown in economic growth of processing industries of the national economy, due to changes in the foreign economic vector of the country, the transformation of the nature and growth of competitive and economic relations, the need to revise innovation policy, is critical to ensure the efficiency of innovation of industrial enterprises. The implementation of progressive changes requires the systematic use of knowledge, the latest technologies, intangible assets, which determines innovation by the primary activators of the development of such enterprises. This stimulates them to reconsider the principles of development management, especially in the context of paradigmatic changes in management theory in the direction of using innovative approaches, opportunities and mechanisms, rethinking classical development theories and forming a new methodological basis on the basis of modern concepts.

The problems of innovative development of enterprises today are considered through the prism of two main theories: the theory of development, which is based on the integrity of the enterprise as an economic system and focuses on the transformation of the system as a whole, and systems theory, which takes into

\footnotetext{
Corresponding author:

${ }^{1}$ National Technical University of Ukraine «Igor Sikorsky Kyiv Polytechnic Institute», Ukraine.

E-mail: alsu@i.ua

ORCID: https://orcid.org/0000-0002-8623-4507

ResearcherID: https://publons.com/researcher/2933513/alla-dunska/

${ }^{2}$ National Technical University of Ukraine «Igor Sikorsky Kyiv Polytechnic Institute», Ukraine.

E-mail: boyarinovaea@ukr.net

ORCID: https://orcid.org/0000-0001-5879-2213

${ }^{3}$ National Technical University of Ukraine «Igor Sikorsky Kyiv Polytechnic Institute», Ukraine.

E-mail: marina.kravchenko.kpi@gmail.com

ORCID: http://orcid.org/0000-0001-5405-0159
} 
account structural features, processes that ensure the functioning of the enterprise as an economic system aimed at achieving the goal in the external environment, which is also determined by a certain structure and features.

The scientific basis of the theory of development and, in particular, the theory of innovative development is laid in the works of many domestic and foreign scientists, including $M$. Kondratieff (long wave theory) (Kondratieff, 2003), J. D. Bernal, G. Mensha (technological stalemate), A. Kleiknecht, S. Kuznets, B. Twiss, C. Freeman, J. Clark, L. Soete (Freeman, Clark, Soete, 1982), N. Nelson (the concept of the national innovation system), L. Leidesdorf (triple helix theory). In this direction it should be noted the works of J. Schumpeter (theory of economic development) (Schumpete, 1934), P. Drucker (theory of innovative economics of entrepreneurial type) (Drucker, 1993), who explored the entrepreneurial approach to development as an activator of innovation processes; discrete development on an innovative basis over time; the primacy of innovation compared to other activators of development, which form not only innovation but also business potential and develop new forms of business. Yu. Yakovets, S. Glazyeva (Yakovets, 2004; Glazyev, 2012), which identified the factors of innovative development of the enterprise within the fifth, sixth or seventh technological modes and innovation capacity of each of the factors of economic development. Acquisition of competitive advantages of development on the basis of innovations, formation of a policy of protection of large enterprises from competition of subversive innovations were devoted to works of M. Porter (theory of competitive advantages) (Porter, 1980), K. Christensen (concept of "subversive" innovations) (Christensen, 1997). Among the scientists developing the latest theories of innovative development are F. Jansen, F. Hayek (theory of intellectual technology) (Jansen, 2000; Hayek, 2001), G. Itzkowitz (triple helix theory) (Itskowitz, 2010), H. Chesbrough (the concept of open innovation) (Chesbrough, 2003; 2006), P. Gloor (model of innovation collaboration networks) (Gloor, 2006 ), V. Hwang, G. Horowitt (concept "Tropical Forest of Innovations") (Hwang, Horowitt, 2012), which defined a set of patterns of innovative development: cyclical acquisition of innovative experience, the need for economic relations to accumulate intellectual potential and use it as a resource for innovative development; implementation of innovative development in the ecosystem at parity of economic interests of the enterprise with the subjects of interaction; use of the model of open innovations for formation of policy of economic behavior; creating innovations in the process of collaborative relationships with stakeholders. The scientific works of I. Ansoff, M. Zgurovsky (Zgurovsky, 2003), G. Kleiner
(Kleiner, 2012), J. Kornai (Kornai, 2002), G. Milner, M. Kravchenko (Kravchenko, 2017) are devoted to the problems of the system approach. and others.

Paying tribute to the significant contribution of these scientists, it should be noted that Ukrainian industry has a number of features, including lack of capital resources, obsolescence of technical and technological base, deformed management structure, which complicate, and sometimes impossible, the use of classical theories of enterprise development. approach to the transformation of economic systems. This necessitates a revision of the theoretical and methodological basis, which should be used in the management of industrial enterprises, based on the ontological connection of development theory and systems theory. This determines the objective need to form a scientific and methodological approach to determining the vectors of innovative development of industrial enterprises as a tool for establishing the trajectory of innovation in the development of innovation potential and environmental impact.

\section{Organizational and managerial approach to ensuring innovative development}

Ensuring the development of industrial enterprises should be based on the definition of a certain trajectory. At the same time, the formation of such a trajectory should take into account the external influences on the enterprise, the level of development of innovation potential, targets and orientation of the enterprise, which is set out in detail by the author in the works (Gavrysh, Dunska, Zhygalkevich, Kravchenko, 2019). In addition, the regulation of the trajectory in accordance with the targets of development should be based on the use of the results of systematic economic and managerial diagnostics, in the existing conditions, which allows to establish their inconsistency with the target level for management decisions to eliminate negative trends (Boiarynova, Kopishynska, Hryhorska, 2019; Gavrysh, Boiarynova, 2017).

The development of an industrial enterprise can be conditionally represented as the transition of the production and commercial system from one state to another, and the new state should have more progressive, qualitative and quantitative characteristics (Figure 1). The incentive to initiate the process of qualitative changes in the system and its transition to a new state are management decisions that are made at the industrial enterprise, and take into account the disturbances that occur in the external environment of enterprises.

To ensure the effective innovative development of an industrial enterprise, it is important to determine the conditions under which the system of goal-setting of the enterprise is formed: the economy is in a declining 
or growing wave of market conditions. Trends in the external environment determine the nature of innovative development of an individual enterprise, in particular in terms of determining the predominant type of innovation that forms the basis of innovative development of the enterprise.

With this in mind in industrial enterprises under different environmental conditions, given the type of innovation that prevails, it is advisable to determine the set of organizational and functional subsystems that play a key role in innovation transformations let's call it "enhanced action unit". This unit covers the functional units of the industrial enterprise, which are the main generators and consumers of innovation.

Thus, during the downturn of the economy, it is advisable for industrial enterprises to focus on active innovation on the basis of technical and technological, production innovations, which should result in new products, technologies, technical and technological solutions (Figure 2). At the peak of the economic situation on the growing wave of enterprises will try to maintain their position, and therefore they need to focus more on organizational and managerial and marketing innovations, which result in new approaches to managing the company or its departments, new methods of organization works, marketing innovations, market innovations, etc. (Figure 3).

At the same time, the role of processes that ensure consistency and implementation of innovative development is changing. In the declining wave, innovation development occurs through diagnostic and interaction processes, as technical and technological innovations involve a sufficiently high level of innovation potential of the enterprise, conducting its own research or attracting external sources of innovative ideas, effective implementation of which depends on relationships between functional units.

From the given figures it is possible to draw a conclusion that at different stages of economic development it is expedient for the industrial enterprises to concentrate the efforts on various functional subsystems in structure of organizational maintenance of innovative development.

\section{Types of targeted innovation orientation of the enterprise}

Effective management of functional subsystems is carried out under the conditions of clear definition of the purposes which the enterprise aspires to reach, that is for maintenance of development at the enterprise its target innovative orientation should be specified.

Depending on the level of development of the innovative potential of the enterprise and the strength of the impact of the external environment in which the enterprise operates, we propose to identify seven types of targeted innovation orientation of industrial enterprises, namely:

1. Supportive - involves the operation of the enterprise in conditions of low level of innovation potential and low level of turbulence of the environment. Innovations do not have a high level of novelty, they have an improving character.

2. Preventive - appropriate for an enterprise that has an innovation potential below average, given the average level of turbulence in the environment and involves tracking adverse changes in certain parameters of the innovation potential of the enterprise and its environment.

3. Synergetic - takes place under the condition of strong stimulating influence of the external

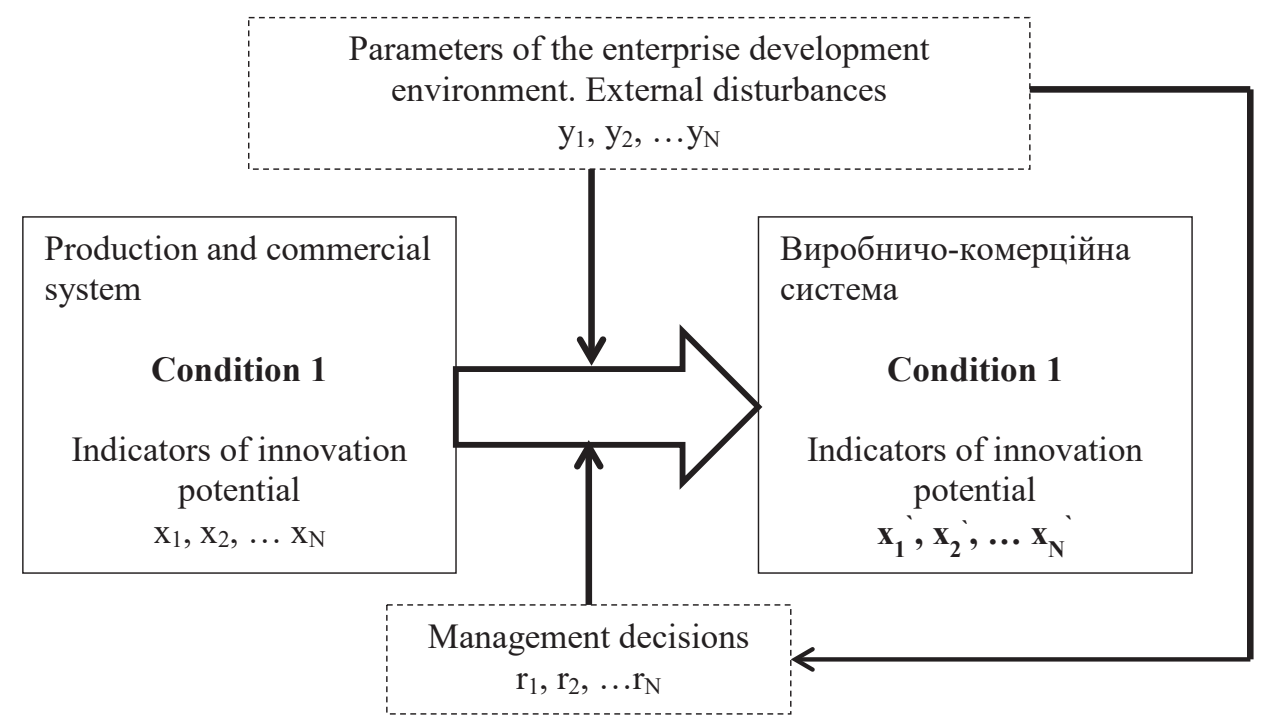

Figure 1. Schematic representation of the process of industrial enterprise development

Source: generated by the author 


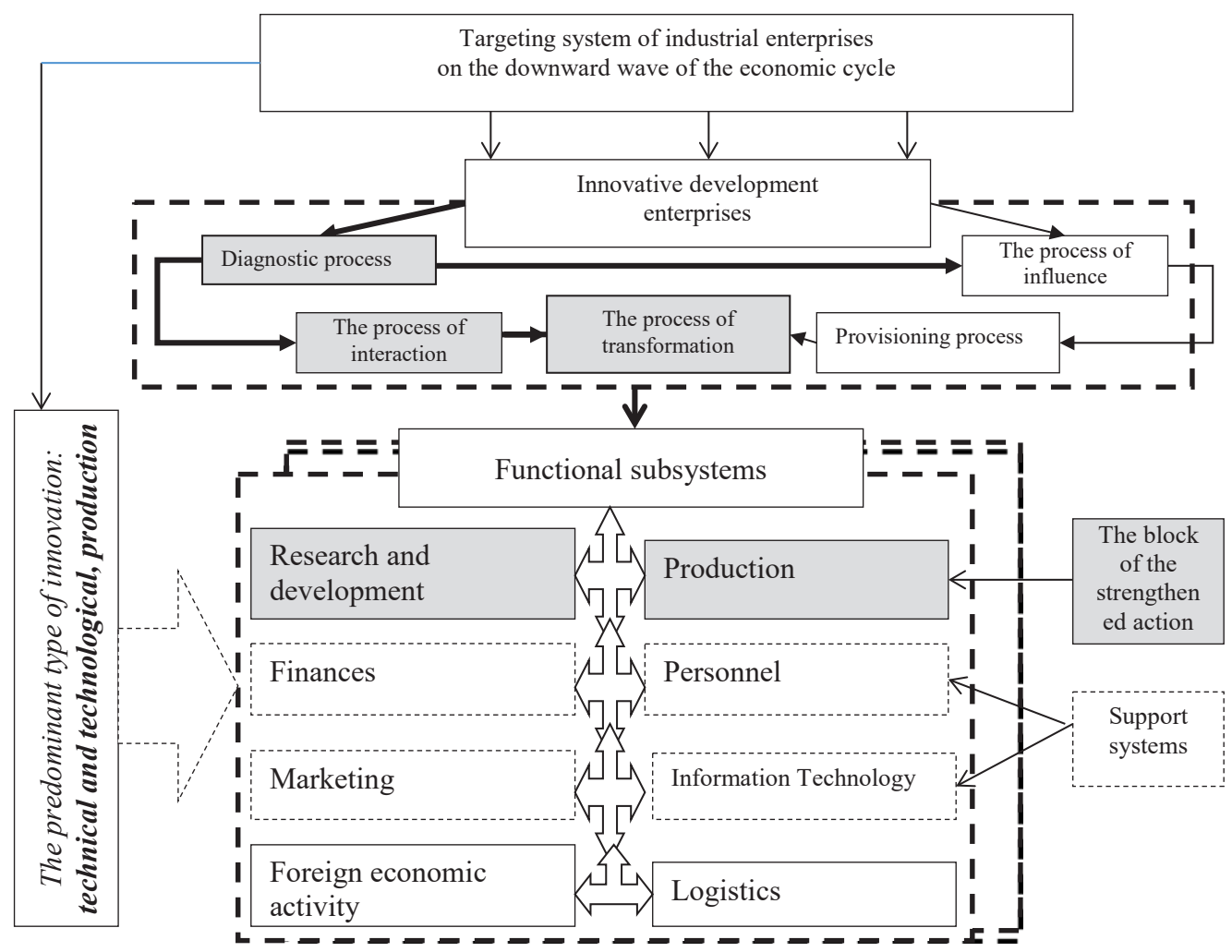

Figure 2. Organizational support of innovative development of an industrial enterprise in the declining wave of economic conditions

Source: developed by the author

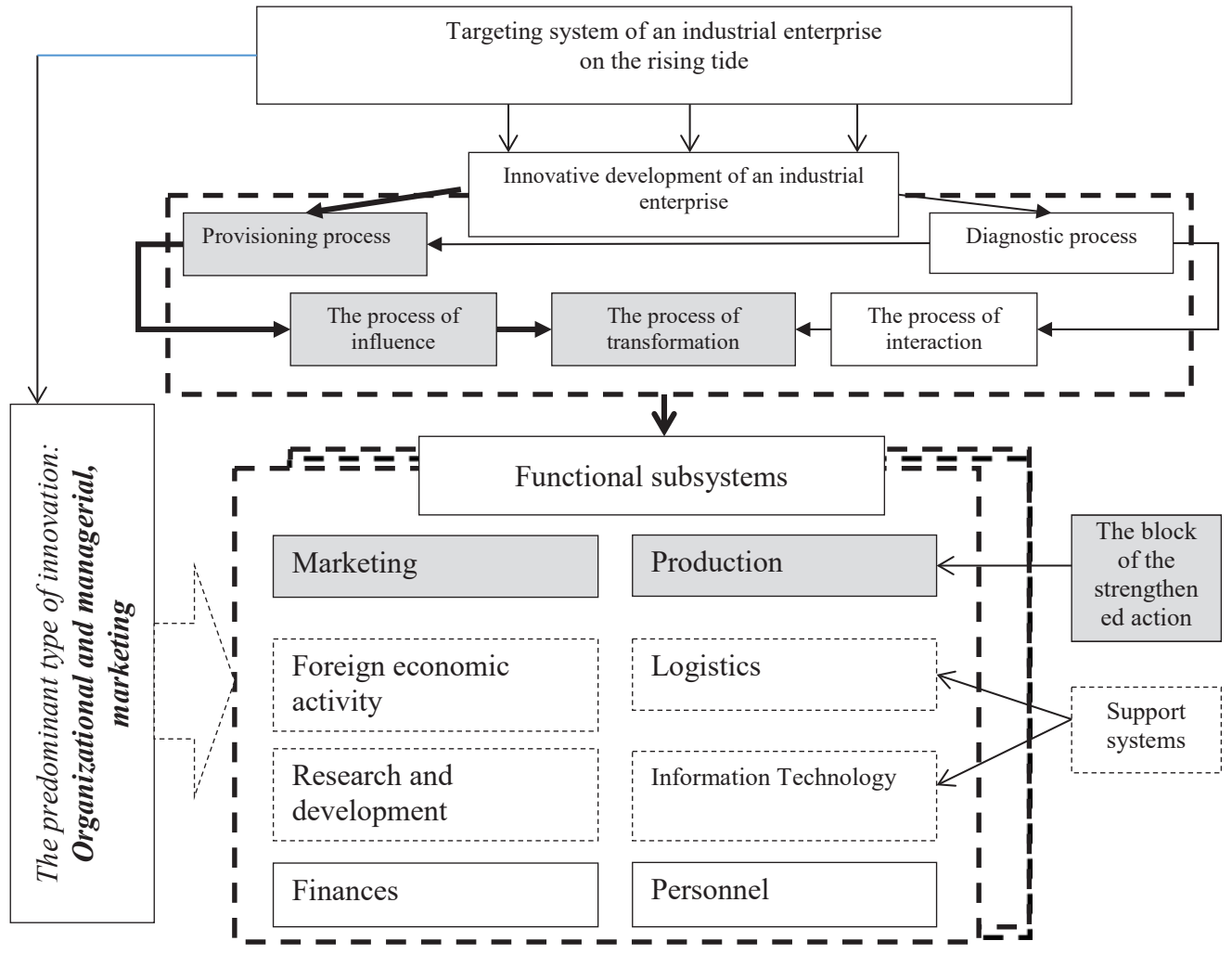

Figure 3. Organizational support of innovative development of an industrial enterprise in terms of ensuring sustainable development

Source: developed by the author 
environment on the development of the enterprise and is recommended for those enterprises that have a high level of innovation potential, which allows to react in time to changes in the external environment.

4. Protective - provides an opportunity to operate in a high level of turbulence of the external environment and a low level of innovation potential of the enterprise, which necessitates the company to take immediate measures to resist external pressure by increasing the level of innovation potential.

5. Balanced - provides an opportunity for the company to be in equilibrium and choose the direction of its development in terms of the average level of development of innovation potential and the average level of environmental impact.

6. Absorbent - provides an opportunity to respond and "mitigate" the negative impact of the external environment due to a sufficiently high level of innovation potential.

7. Niche - focuses the company on the accumulation of resources for radical change, as it provides a strong innovative potential of the enterprise in a weak environment.

Each of the above types of innovation focuses on the need to identify appropriate strategies, programs and projects that are tools to ensure the development of the enterprise under a certain level of environmental impact and the level of development of innovation potential. In fig. 4 specifies which innovation strategies, programs and projects should be used to ensure effective innovative development of industrial enterprises within each of the identified types of targeted innovation.

It should be noted that the development of the enterprise is through the transformation of functional subsystems based on a set of processes of interaction, diagnosis, impact and provision. Therefore, for each type of targeted innovation, key processes and subsystems have been identified, which will primarily be involved in the process of innovation development (Figure 4).

In general, taking into account changes in the external environment and the innovative potential of the enterprise provides an opportunity to identify three vectors of development of the industrial enterprise:

1. Innovation-adaptive vector, which describes the company's intentions to adapt to the growing influence of the external environment without spending efforts to increase capacity.

2. Innovation-balanced vector, which characterizes the company's efforts to ensure its sustainable development in terms of increasing environmental impact.

3. Innovation-concentrated vector, which involves the concentration of efforts of the enterprise primarily on the development of its innovation potential.

\section{Survey methodology}

We propose to base the determination of the appropriate vector of development for industrial enterprises and the subsequent forecasting of the results of the introduction of innovative development on the results of correlation analysis.

To analyze the relationship between the parameters of the external and internal environment, we have formed the appropriate groups of parameters, taking into account the possibility of obtaining the necessary reliable data for analysis.

The parameters of the external environment included factors that characterize the state of innovation in industry, as industry-wide trends in innovation affect the nature of innovation in an individual enterprise, as well as expert assessments of direct environmental factors of industrial enterprises, which we identified and described in work (Dunska, 2013). The list of environmental parameters is given in table 1 .

In the table 2 and 3 respectively show the composition of the parameters of the innovation potential of the enterprise and the composition of the parameters that characterize the results of the enterprise.

\section{Finding}

The study was tested on the example of leading enterprises of pulp and paper enterprises of Ukraine: PJSC "Malyn Paper Factory-Weidmann", PJSC "Kyiv Cardboard and Paper Mill", PJSC "Rubizhansky Cardboard and Packaging Plant", Banknote Paper Factory of the National Bank of Ukraine. Specific information materials were the data of economic reporting for the period from 2009 to 2020 and the results of expert assessments.

Correlation methods of analysis have a number of limitations, as they provide averaged dependences of the interaction of the parameters of the external and internal environments of enterprises and poorly take into account the specifics of an individual enterprise. However, the calculation of correlations makes it possible to determine the strength and nature of the mutual influence of parameters that characterize the external and internal environment of the enterprise, and, accordingly, to identify the most important of them to choose to ensure the development of individual enterprises.

A key point in the analysis of the calculated correlation coefficients is to determine the importance or non-importance of the relationships between the parameters by setting the threshold of statistical significance $\rho$. Determining the quantitative threshold of statistical significance is not a clearly formalized task and largely depends on experience and intuition. In the general case, the values of the correlation coefficient range from -1 to +1 . Negative values of the coefficient indicate the inverse relationship 
[в!ฺนวฺоd

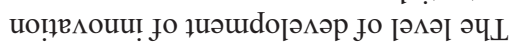

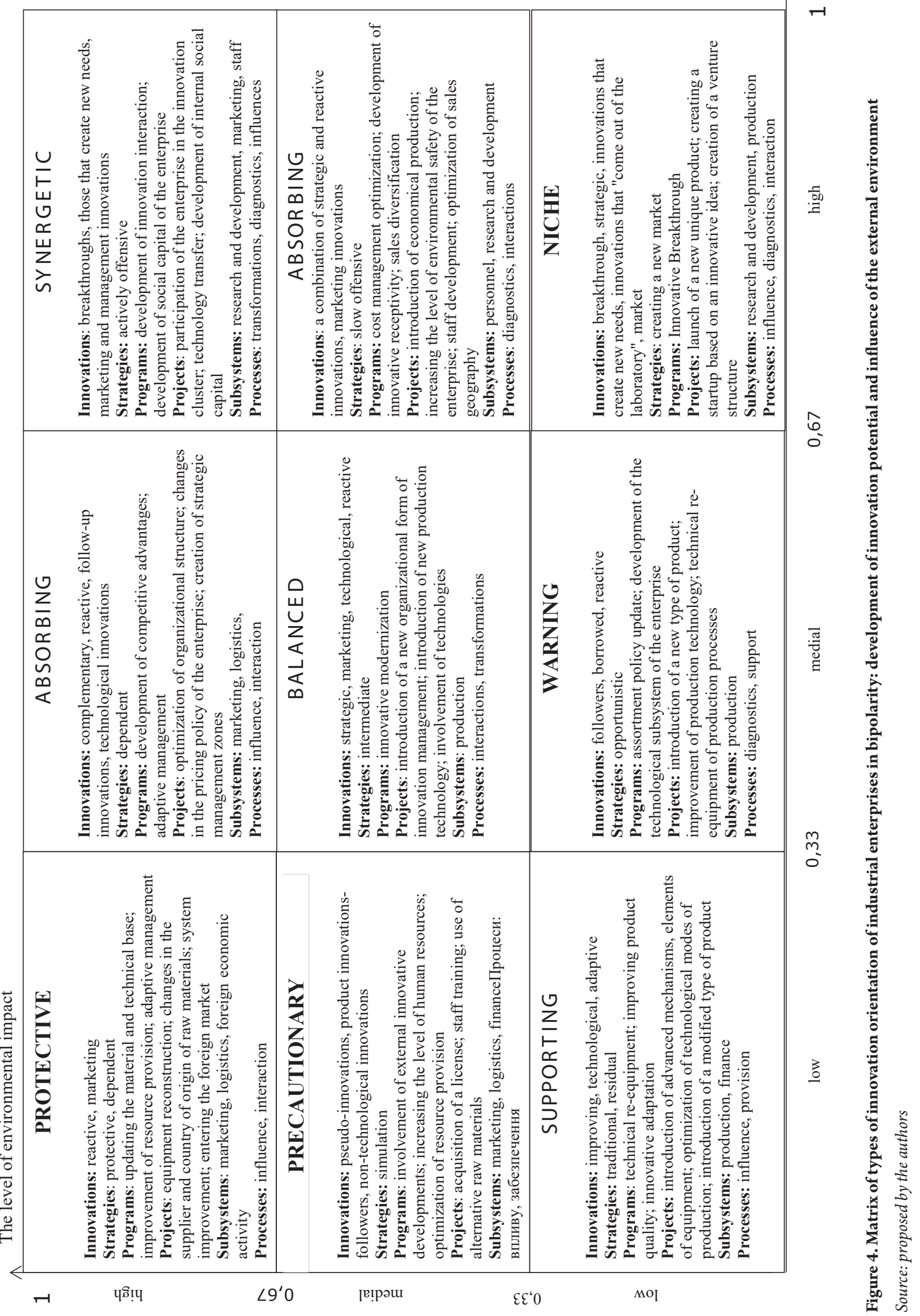


Vol. 7 No. 4, 2021

Level of influence external environment

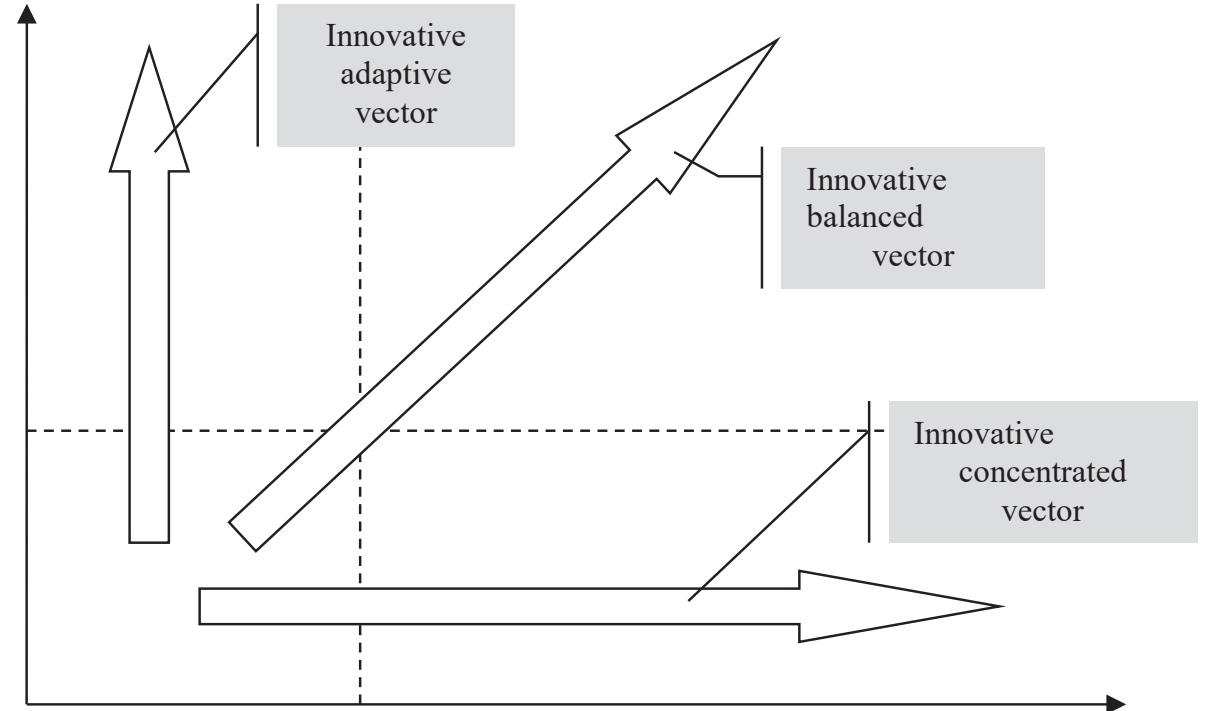

The level of development of innovation potential

a) without taking into account the nature of the impact of the external environment

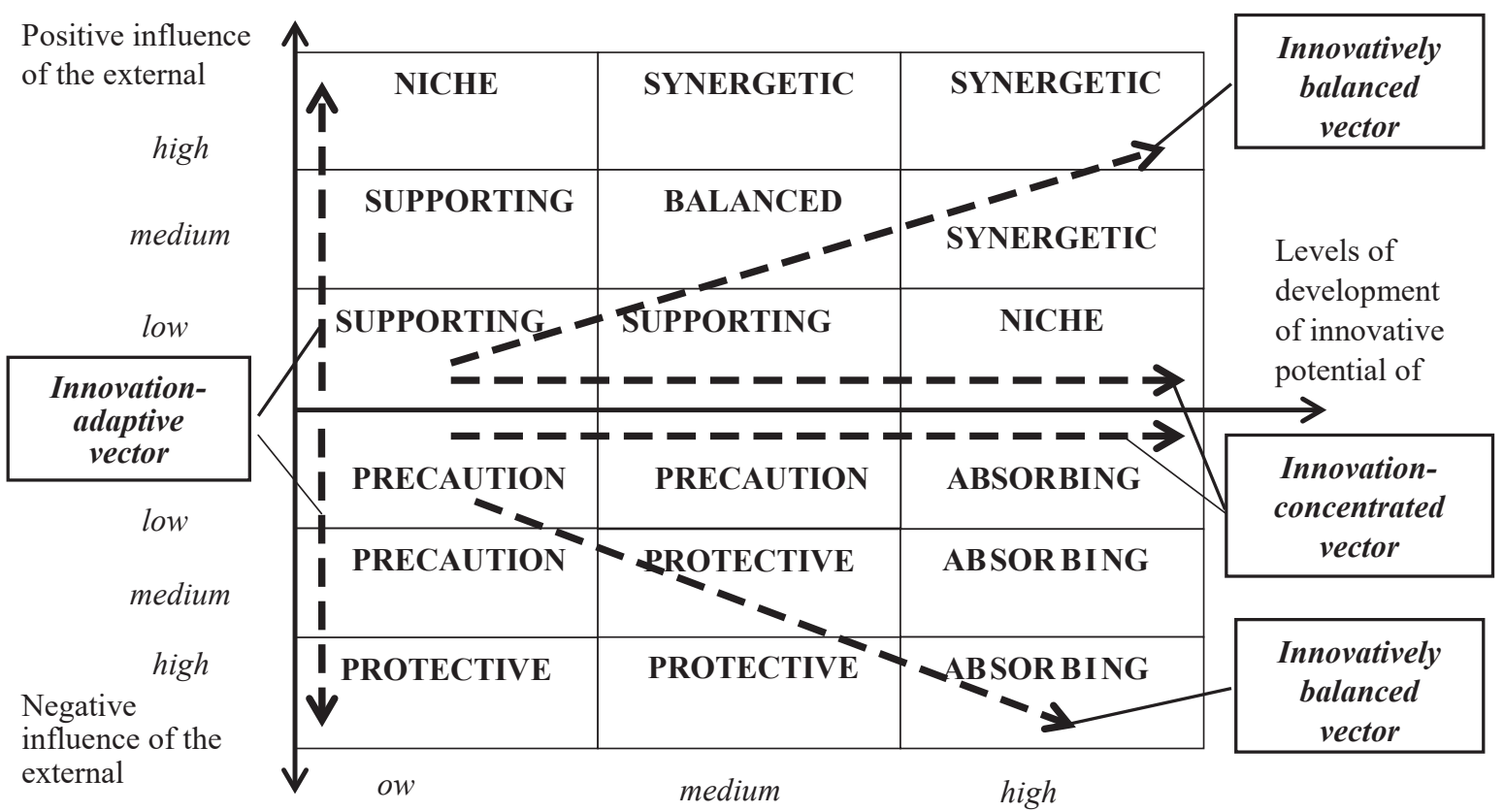

b) taking into account the nature of the impact of the outdoor environment

Figure 5. Vectors of innovative development of enterprises

Source: suggested by the authors

between the parameters. In (Glass and Stanley, 1976), the following interpretation of correlation coefficients is proposed, which will be used by us to analyze the results of calculations: $+1,00$ - deterministic (direct close) relationship; about +0.50 - weak connection; 0.00 - no connection; about -0.50 - weak connection; -1.00 - deterministic (inverse close) connection.

As a result of processing the collected data, we built matrices of pairwise correlation coefficients for environmental parameters, innovation potential, performance and environmental parameters and parameters of innovation potential and performance of enterprises.

Based on the logical analysis of the nature and nature of the relationships of the studied parameters, we chose the threshold of statistical significance $\rho n= \pm 0.5$. The obtained calculations make it possible to conclude that there is a direct relationship between 
Table 1

List of parameters of the external environment of industrial enterprises

\begin{tabular}{|c|l|c|}
\hline $\begin{array}{c}\text { Designation } \\
\text { (environment })\end{array}$ & \multicolumn{1}{|c|}{ Parameters of the external environment of the enterprise } & Units of measurement \\
\hline $\mathbf{E}_{1}$ & Volumes of financing of innovative activity in branch & UAH million \\
\hline $\mathbf{E}_{2}$ & Number of enterprises in the industry that have implemented innovations & pcs \\
\hline $\mathbf{E}_{3}$ & The number of introduced innovative types of products at the enterprises of the branch & units \\
\hline $\mathbf{E}_{4}$ & The number of implemented advanced technological processes at the enterprises of the branch & units \\
\hline $\mathbf{E}_{5}$ & $\begin{array}{l}\text { The number of implemented low-waste, resource-saving or non-waste technologies at the } \\
\text { enterprises of the branch }\end{array}$ & person \\
\hline $\mathbf{E}_{6}$ & Number of inventors, authors of industrial designs and innovation proposals & units \\
\hline $\mathbf{E}_{7}$ & Number of applications for inventions, utility models and industrial designs filed in the field & UAH thousand \\
\hline $\mathbf{E}_{8}$ & The volume of sold innovative products of CPP outside Ukraine & points \\
\hline $\mathbf{E}_{9}$ & The strength of the impact of changing conditions on the activities of enterprises in the industry & points \\
\hline $\mathbf{E}_{10}$ & Intensity of technological changes in the industry & points \\
\hline $\mathbf{E}_{11}$ & The degree of consumer influence on the activities of enterprises in the industry & points \\
\hline $\mathbf{E}_{12}$ & The degree of influence of state regulation on the activities of enterprises in the industry & points \\
\hline $\mathbf{E}_{13}$ & The degree of influence of the resource base of the industry & points \\
\hline $\mathbf{E}_{14}$ & The degree of influence of environmental factors on the activities of enterprises in the industry & \\
\hline
\end{tabular}

Source: compiled by the authors.

Table 2

List of parameters of innovation potential of industrial enterprises

\begin{tabular}{|c|c|c|}
\hline $\begin{array}{l}\text { Designation } \\
\text { (innovative } \\
\text { potential) }\end{array}$ & Parameters of innovation potential of the enterprise & Units of measurement \\
\hline IP $\mathbf{P}_{1}$ & Costs of acquisition of non-current assets & UAH thousand \\
\hline $\mathbf{I P}_{2}$ & The degree of depreciation of fixed assets & $\%$ \\
\hline $\mathbf{I P}_{3}$ & Capacity utilization level & $\%$ \\
\hline $\mathbf{I P}_{4}$ & Return on assets & $\%$ \\
\hline IP $\mathbf{P}_{5}$ & The share of electricity costs in the structure of production costs & $\%$ \\
\hline $\mathbf{I P}_{6}$ & The share of material costs in the structure of production costs & $\%$ \\
\hline $\mathbf{I P}_{7}$ & The level of provision of the enterprise with material resources. & points \\
\hline IPs & Number of new and modernized technological processes put into operation in the current year & units \\
\hline IP $_{9}$ & The value of the coefficient of maneuverability & $\%$ \\
\hline $\mathbf{I P}_{10}$ & Coefficient of financial independence & $\%$ \\
\hline IP11 & Coefficient of financial stability & $\%$ \\
\hline $\mathbf{I P}_{12}$ & Assessment of the innovative orientation of the enterprise & points \\
\hline $\mathbf{I P}_{13}$ & The level of innovative receptivity of staff & points \\
\hline $\mathbf{I P}_{14}$ & The growth rate of the average number of employees & without measurement \\
\hline $\mathbf{I P}_{15}$ & The share of labor costs in the structure of production costs & $\%$ \\
\hline $\mathbf{I P}_{16}$ & Productivity & UAH / person \\
\hline $\mathbf{I P}_{17}$ & Research and development costs & UAH thousand \\
\hline $\mathbf{I P}_{18}$ & Selling expenses & UAH thousand \\
\hline IP 19 & The level of use of information technology & points \\
\hline $\mathbf{I P}_{\mathbf{2 0}}$ & Efficiency of communication channels & points \\
\hline $\mathbf{I P}_{21}$ & The share of exports in total production & $\%$ \\
\hline $\mathbf{I P}_{22}$ & The share of exports to foreign countries in total production & $\%$ \\
\hline
\end{tabular}

Source: compiled by the authors

the degree of influence of the resource base of enterprises in the industry $\left(E_{13}\right)$ and the assessment of the impact of changes in environmental conditions on the activities of enterprises $\left(E_{9}\right)$, the degree of influence of state regulation $\left(E_{12}\right)$. the degree of influence of environmental factors $\left(E_{14}\right)$ and the share of enterprises in the industry that have implemented innovations $\left(E_{2}\right)$.
Feedback is present between the impact of government regulation $\left(E_{12}\right)$ and the number of new products developed in the industry $\left(E_{3}\right)$.

When intensifying innovative development, it is important to assess the nature and direction of the impact of the external environment on the innovative potential of the enterprise. The analysis of the obtained 
Vol. 7 No. 4, 2021

Baltic Journal of Economic Studies

Table 3

List of parameters of results of industrial enterprises

\begin{tabular}{|c|l|c|}
\hline Designation (rezult) & \multicolumn{1}{|c|}{ Parameters of efficiency of enterprise activity } & Units of measurement \\
\hline $\mathbf{R}_{\mathbf{1}}$ & Production volume & UAH thousand \\
\hline $\mathbf{R}_{\mathbf{2}}$ & Sales volume & UAH thousand \\
\hline $\mathbf{R}_{\mathbf{3}}$ & Sales revenue & UAH thousand \\
\hline $\mathbf{R}_{\mathbf{4}}$ & Net profit (loss) & UAH thousand \\
\hline $\mathbf{R}_{\mathbf{5}}$ & Product profitability & without measurement \\
\hline $\mathbf{R}_{\mathbf{6}}$ & Return on assets & without measurement \\
\hline $\mathbf{R}_{\mathbf{7}}$ & Return on equity & without measurement \\
\hline $\mathbf{R}_{\mathbf{8}}$ & Total liquidity ratio & pennies \\
\hline $\mathbf{R}_{\mathbf{9}}$ & Costs per 1 UAH. sold products & $\%$ \\
\hline $\mathbf{R}_{\mathbf{1 0}}$ & Dynamics of export growth & \\
\hline
\end{tabular}

Source: compiled by the authors

calculations shows that the most significant factor of the external environment is the assessment of the degree of consumer influence on the activities of enterprises in the industry $\left(E_{11}\right)$. The greatest closeness of the relationship can be traced between this indicator and the following parameters of innovation potential: the number of new and modernized technological processes put into operation in the current year $\left(\mathrm{IP}_{8}\right)$ : the growth of this indicator indicates the improvement of the innovative level of production and products in accordance with the growing demands of consumers;

- the level of innovative receptivity of staff $\left(\mathrm{IP}_{13}\right)$ : the adaptation of technological processes to the new needs of consumers requires an appropriate level of creativity from employees of enterprises;

- costs of research and development (IP $\left.{ }_{17}\right)$ : increasing market power of consumers requires companies to find new, non-standard solutions to meet the needs of consumers, and, consequently, leads to increased costs of research and development;

- sales costs $\left(\mathrm{IP}_{18}\right)$ : increasing the number of consumers requires higher costs for their supply of products, increasing consumer demand requires the establishment of efficient operation of sales channels.

It should be noted that the correlation analysis showed a close relationship between the amount of funding for innovation in the industry $\left(E_{1}\right)$ and the level of innovation susceptibility of staff in the industry $\left(\mathrm{IP}_{13}\right)$ : the correlation coefficient is 0.82 (according to our research from 2000 to 2005 years, the value of this ratio was 0.55 ). It is obvious that the tendencies to increase the volume of funding for innovation in the industry will lead to an increase in the innovative receptivity of staff at each individual enterprise. On the other hand, awareness of the role of innovative transformations in enterprises contributes to increasing funding for innovation, quantitative and qualitative growth of innovation results, increasing the number of employees in the innovation sector and, consequently, increasing the innovation sensitivity of staff in general.
The analysis of the correlations between the indicators of innovation potential and the parameters that characterize the results of the enterprise, provided an opportunity to identify the most significant factors of innovation potential on which the effectiveness of the enterprise depends. Namely, there is a close connection between:

- the level of capacity utilization $\left(\mathrm{IP}_{3}\right)$ and production and sales volumes $\left(\mathrm{R}_{1}, \mathrm{R}_{2}\right)$;

- the number of innovative technological processes put into operation $\left(\mathrm{IP}_{8}\right)$ and the company's profit $\left(\mathrm{R}_{4}\right)$; - costs of research and development $\left(\mathrm{IP}_{17}\right)$ and sales revenue $\left(R_{3}\right)$, costs per 1 UAH of sold products $\left(R_{9}\right)$, and the dynamics of export growth $\left(\mathrm{R}_{3}\right)$.

There are also correlations in the structure of innovation potential parameters. In particular, the calculations showed the presence of feedback between the level of security of the enterprise with material resources $\left(\mathrm{IP}_{7}\right)$ and the number of new and modernized technological processes $\left(\mathrm{IP}_{8}\right)$; direct links with the value of the correlation coefficient greater than 0.95 are present between the value of the share of material costs in the cost structure $\left(\mathrm{IP}_{6}\right)$ and the level of material security of the enterprise, between the value of the share of electricity costs in the cost structure $\left(\mathrm{IP}_{5}\right)$ and the number new and modernized technological processes $\left(\mathrm{IP}_{8}\right)$; the growth rate of the number of employees $\left(\mathrm{IP}_{14}\right)$ and labor productivity $\left(\mathrm{IP}_{16}\right)_{\text {; }}$ the level of innovative susceptibility of personnel $\left(\mathrm{IP}_{13}\right)$ and the share of exports to industrialized countries in total production $\left(\mathrm{IP}_{22}\right)$.

These results of the analysis of the relationship between the parameters of innovation potential of enterprises, environmental parameters and performance of enterprises provide an opportunity to build a linear multiple regression equation for each vector of development, which allows to analyze the relationship between several variables and assess their impact on the dependent variable. The equation for the innovation-adaptive vector should be based on the relationship between corporate profits $\left(R_{4}\right)$, the number of implemented innovation processes $\left(\mathrm{IP}_{8}\right)$ 
Table 4

Design of vectors of development of pulp and paper enterprises

\begin{tabular}{|c|c|c|c|c|}
\hline $\begin{array}{l}\text { Selection } \\
\text { criterion }\end{array}$ & $\begin{array}{l}\text { Development } \\
\text { vector }\end{array}$ & Terms of selection & Model for forecasting & Explanation \\
\hline \multirow{3}{*}{ 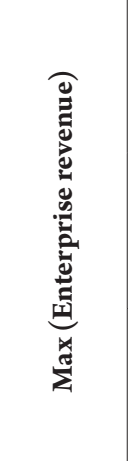 } & $\begin{array}{c}\text { Innovatively } \\
\text { balanced }\end{array}$ & $\begin{array}{l}\text { Rising costs for } \\
\text { innovation in the industry } \\
\text { Increasing the level of } \\
\text { innovation receptivity }\end{array}$ & $\begin{array}{c}\mathbf{Y}_{13}=\mathbf{A}_{01}+\mathbf{A}_{11}{ }^{*} \\
{ }^{*} \mathbf{X}_{1}+\mathbf{A}_{12}{ }^{*} \mathbf{X}_{2}\end{array}$ & $\begin{array}{c}\mathrm{Y}_{13}-\text { revenue of enterprises from sales of products }\left(\mathrm{R}_{3}\right) \text {, } \\
\mathrm{X}_{1} \text { - costs of innovation in the industry }\left(\mathrm{E}_{1}\right) \\
\mathrm{X}_{2} \text { - the level of innovative susceptibility of enterprise } \\
\text { personnel }\left(\mathrm{IP}_{13}\right)\end{array}$ \\
\hline & $\begin{array}{l}\text { Innovation- } \\
\text { concentrated }\end{array}$ & $\begin{array}{l}\text { The growth of enterprise } \\
\text { costs for innovation } \\
\text { Increasing the level of } \\
\text { innovation receptivity }\end{array}$ & $\begin{array}{c}\mathbf{Y}_{\mathrm{IK}}=\mathbf{A}_{02}+\mathbf{A}_{21}{ }^{*} \\
{ }^{*} \mathbf{X}_{3}+\mathbf{A}_{22}{ }^{*} \mathbf{X}_{2}\end{array}$ & $\begin{array}{c}\mathrm{Y}_{\mathrm{IK}}-\text { revenue of enterprises from sales of products }\left(\mathrm{R}_{3}\right) \text {, } \\
\mathrm{X}_{3}-\text { costs of enterprises for innovation }\left(\mathrm{IP}_{17}\right) \\
\mathrm{X}_{2} \text { - the level of innovative susceptibility of enterprise } \\
\text { personnel }\left(\mathrm{IP}_{13}\right)\end{array}$ \\
\hline & $\begin{array}{l}\text { Innovative- } \\
\text { adaptive }\end{array}$ & $\begin{array}{l}\text { Rising costs for } \\
\text { innovation in the industry } \\
\text { Growing consumer } \\
\text { influence }\end{array}$ & $\begin{array}{c}\mathbf{Y}_{\mathrm{IA}}=\mathbf{A}_{03}+\mathbf{A}_{31}{ }^{*} \\
{ }^{*} \mathbf{X}_{\mathbf{1}}-\mathbf{A}_{\mathbf{2}}{ }^{*} \mathbf{X}_{4}\end{array}$ & $\begin{array}{c}Y_{\mathrm{IA}}-\text { revenue of enterprises from sales of products }\left(\mathrm{R}_{3}\right) \\
\mathrm{X}_{1}-\text { costs of innovation in the industry }\left(\mathrm{E}_{1}\right) \\
\mathrm{X}_{4} \text { - level of consumer influence }\left(\mathrm{E}_{11}\right)\end{array}$ \\
\hline
\end{tabular}

Source: developed by the authors

Table 4

Forecasting the development of pulp and paper enterprises

\begin{tabular}{|c|c|c|c|c|c|}
\hline \multirow[t]{2}{*}{ Enterprise } & \multirow{2}{*}{$\begin{array}{c}\text { Development } \\
\text { vector }\end{array}$} & \multirow[t]{2}{*}{ Model for forecasting } & \multicolumn{3}{|c|}{$\begin{array}{c}\text { Enterprise revenue forecast, } \\
\text { thousand UAH }\end{array}$} \\
\hline & & & 2021 & 2022 & 2023 \\
\hline $\begin{array}{l}\text { PJSC "Malyn Paper } \\
\text { Factory-Weidmann" }\end{array}$ & $\begin{array}{l}\text { Innovation- } \\
\text { concentrated }\end{array}$ & $\begin{array}{c}Y_{I K}=110335,1813+49,4127^{*} X_{3}+8410,9133^{*} X_{2} \\
\text { where } Y_{I K}-\text { revenue of enterprises from sales of products }\left(R_{3}\right) \text {, } \\
X_{3} \text { - costs of enterprises for innovation }\left(I P_{17}\right), \\
X_{2} \text { - the level of innovative susceptibility of enterprise } \\
\text { personnel }\left(I P_{13}\right)\end{array}$ & 490436,4 & 626740,6 & 822148,8 \\
\hline $\begin{array}{c}\text { PJSC "Rubizhansky } \\
\text { Cardboard and } \\
\text { Packaging Plant" }\end{array}$ & $\begin{array}{l}\text { Innovatively } \\
\text { balanced }\end{array}$ & $\begin{array}{c}Y_{I 3}=-140689,5637+4029,7835^{*} X_{1}+207600,1961^{*} X_{2} \\
\text { where } Y_{I 3}-\text { revenue of enterprises from sales of products }\left(R_{3}\right) \text {, } \\
X_{1}-\text { costs of innovation in the industry }\left(E_{1}\right), \\
X_{2}-\text { the level of innovative susceptibility of enterprise } \\
\text { personnel }\left(I P_{13}\right)\end{array}$ & 2706275,167 & 3265620 & 4032056 \\
\hline $\begin{array}{l}\text { PJSC "Kyiv } \\
\text { Cardboard and } \\
\text { Paper Mill" }\end{array}$ & $\begin{array}{l}\text { Innovative- } \\
\text { adaptive }\end{array}$ & $\begin{array}{c}Y_{I A}=31821625,3461+1286,2602^{*} X_{1}- \\
3354871,9406^{*} X_{4}, \\
\text { where } Y_{I A}-\text { revenue of enterprises from sales of products }\left(R_{3}\right) \text {, } \\
X_{1}-\text { costs of innovation in the industry }\left(E_{1}\right), \\
X_{4}-\text { level of consumer influence }\left(E_{11}\right)\end{array}$ & 5035822,81 & 5866148 & 7097294 \\
\hline $\begin{array}{l}\text { Ukrainian Paper } \\
\text { LLC }\end{array}$ & $\begin{array}{l}\text { Innovation- } \\
\text { concentrated }\end{array}$ & $\begin{array}{c}Y_{I K}=-90201,4911+438,7126^{*} X_{3}+24003,5649^{*} X_{2} \\
\text { where } Y_{I 3}-\text { revenue of enterprises from sales of products }\left(R_{3}\right) \text {, } \\
X_{1}-\text { costs of innovation in the industry }\left(E_{1}\right), \\
X_{2} \text { - the level of innovative susceptibility of enterprise } \\
\text { personnel }\left(I P_{13}\right)\end{array}$ & 142022,47 & 157764,8 & 175319,2 \\
\hline
\end{tabular}

Source: calculated by the authors

and the strength of consumer influence $\left(E_{11}\right)$; the equation for the innovation-balanced vector should take into account the relationship between the revenue of enterprises from sales $\left(R_{3}\right)$, the cost of innovation in the industry $\left(\mathrm{E}_{1}\right)$ and the level of innovation susceptibility of enterprise personnel $\left(\mathrm{IP}_{13}\right)$; the innovation-focused vector takes into account the relationship between the revenue of enterprises from sales $\left(R_{3}\right)$, the costs of enterprises for innovation $\left(\mathrm{IP}_{17}\right)$ and the level of innovation susceptibility of enterprise personnel $\left(\mathrm{IP}_{13}\right)$.

In the table 5 shows the calculated regression equations for alternative development vectors and forecast indicators of profit and sales revenue at the studied enterprises.

In the case of existing alternative vectors of enterprise development, the one that provides the opportunity to obtain higher economic results is chosen.

\section{Conclusions}

Activation of actions for innovative development of industrial enterprises is preceded by the lack of a proper trajectory, which is determined by the vector. Accordingly, the article forms a scientific and methodological approach to the definition of 
such vectors. Development depends on the type of innovation orientation of the enterprise, due to the available innovation potential and the impact of the external environment. Therefore, the key types of targeted innovation orientation of enterprises should be considered: supportive, preventive, synergistic, protective, balanced, absorbing, niche. Types of orientation are the basis of the developed matrix, which has bipolarities: the development of innovation potential and the impact of the external environment. Its use and application of correlation analysis of indicators of external (external environment of the enterprise) and internal (innovative potential) environment allows to determine vectors of innovative development of industrial enterprise.

Based on the approbation of the approach on the example of pulp and paper enterprises of Ukraine, it was determined that their innovative development should be formed on the basis of three vectors: innovation-balanced, innovation-concentrated and innovation-adaptive, which will provide results in increasing sales revenue. This indicates that the proposed scientific and methodological approach is an effective tool for ensuring the choice of steps and means of effective implementation of innovative development by industrial enterprises.

\section{References:}

Boiarynova, K., Kopishynska, K., \& Hryhorska, N. (2019). Economic and management approach to defining effective projects for enterprise development under risks and uncertainty. Problems and Perspectives in Management, 17(4),299-313. DOI: https://orcid.org/10.21511/ppm.17(4).2019.25

Chesbrough, H. W. (2003). Open innovation: the new imperative for creating and profiting from technology. Boston, Massachusetts: Harvard Business School Press.

Chesbrough, H. W. (2006). Open business models: how to thrive in the new innovation landscape. Harvard: Harvard Business School Press.

Christensen, C. M. (1997). The Innovator's Dilemma: When New Technologies Cause Great Firms to Fail. Boston, MA: Harvard Business School Press.

Drucker, P. F. (1993). Post-capitalist society. New York: Harper Business.

Dunska, A. R. (2013). Indicators of evaluation of innovative potential of development of an industrial enterprise in the conditions of the world market. Bulletin of the National Technical University «KhPI». Series: Technical progress and production efficiency, 44 (1017), 48-58. (in Ukrainian)

Gavrysh, O. A., Dunska, A. R., Zhygalkevich, Zh. M., \& Kravchenko, M. O. (2019). Innovatsiini zasady rozvytku promyslovykh pidpryiemstv $\mathrm{v}$ umovakh intehratsii $\mathrm{v}$ svitovyi ekonomichnyi prostir. Kyiv: Politekhnika. (in Ukrainian)

Freeman, C., Clark, J., \& Soete, L. (1982). Unemployment and Technical Innovation: A Study of Law. W.L.

Gavrysh, O., \& Boiarynova, K. (2017). The methodological approach to monitoring of the economic and functional state of innovation-oriented machinery engineering enterprises at the modern technological modes. Economic Annals-XXI, 164 (3-4), 65-70. DOI: https:/\%orcid.org/10.21003/ea.V164-15

Glass, J., \& Stanley, J. (1976). Statisticheskie metody v pedagogike i psihologii [Statistical methods in pedagogy and psychology]. Moscow: Progress. (in Russian)

Glazyev, S. Yu. (2012). Sovremennaya teoriya dlinnykh voln v razvitii ekonomiki [Modern theory of long waves in economic development]. Economic science of modern Russia, 2(57), 27-42. (in Russian)

Gloor, P. A. (2006). Swarm creativity: competitive advantage through collaborative innovation networks. New York: Oxford University Press.

Hayek, F. A. (2001). Individualism and economic order. Moscow: Izograf.

Hwang, V. W., \& Horowitt, G. (2012). The Rainforest: The Secret to Building the Next Silicon Valley; Regenwald: Los Altos Hills, CA, USA.

Itskowitz, G. (2010). Triple Helix. Universities - enterprises - state. Innovation in action. Trans. from English. Tomsk: Tomsk Publishing House. State University of Control Systems and Radio Electronics. (in Russian)

Jansen, F. (2000). The age of innovation. London: Prentice Hall.

Kleiner, G. B. (2012). Sistemnaya ekonomika - novoye napravleniye v ekonomicheskoy teorii [System economics - a new direction in economic theory]. Kazan: KFU. Available at: www.kpfu.ru/docs/F722052917/ KazanKFU.ppt (in Russian)

Kondratieff, N. D. (2003). Bol'shiye tsikly kon"yunktury i teoriya predvideniya. Izbrannyye trudy [Large Cycles of Conjuncture and the Theory of Foreseeing. Selected Works]. Voprosy ekonomiki, 8, $153-154$. DOI: https: // doi.org/10.32609/0042-8736-2003-8-153-154

Kornai, J. (2002). Sistemnaya paradigma v ekonomike [System paradigm in economics]. Economic issues, 4, 17-23. (in Russian)

Kravchenko, M. (2017). Econometric analysis of machine-building enterprises' sustainability in the context of neo-system paradigm. Scientific Papers of the University of Pardubice. Series D: Faculty of Economics and Administration, no. 41, vol. XXIV, pp. 79-89. 
Porter, M. E. (1980). Competitive strategy: techniques for analyzing industries and competitors. Toronto: The Free Press.

Schumpeter, J. (1934). Theory of Economic Development: An Inquiry into Profits, Capital, Credit, Interest, and the Business Cycle. Cambridge, MA: Harvard University Press.

Yakovets, Yu. V. (2004). Epohalnyie innovatsii XXI veka [Epochal innovations of the XXI century]. Moscow: Ekonomika. (in Russian)

Zgurovsky, M. (2003). Suspilstvo znan ta informatsiyi - tendentsiyi, vyklyky, perspektyvy [Society of knowledge and information - trends, challenges, prospects]. Dzerkalo tyzhnya. Available at: http://gazeta.dt.ua/ ECONOMICS/suspilstvo_znan_ta_informatsiyi_tendentsiyi,_vikliki,_perspektivi.html (in Ukrainian) 